Covered in: ERIH PLUS, CEEOL, Index Copernicus, CrossRef, CrossCheck, J-Gate, Google Scholar, Ideas RePeC, Econpapers, Socionet, KVK, WorldCat.

2020, Volume 8, Issue 1, pages: 33-43 | doi: 10.18662/lumenphs/8.1/34

\section{Transhumanism as Barbarism}

\section{George COLANG', Loredana VLAD 2}

${ }^{1} \mathrm{PhD}$ Lecturer Bioterra University of Bucharest, Romania georgecolang@yahoo.com

${ }^{2}$ PhD Assistant, Ştefan cel Mare University of Suceava, Romania, loredana.vlad@,fdsa.usv.ro

\begin{abstract}
In this article, we will consider how the alterity is transformed into a new form of barbarism in the context of the increasingly accentuated development of human bioenhancement technologies. If in the beginning, barbarism was by excellence the otherness, the stranger, the unknown, today we have to deal with a strange approach were the human is transformed and adapted to the consumerism market. In this way, as we will see at the beginning of the article, barbarism never breaks from civilization, but remains not beyond the city and even more not over humanity itself. It is important to know that barbarism doesn't have just a negative perspective but has an approach within all the unknown things that are viewed as skeptical or with disregard. Next, we will talk about transhumanism as a transition to the otherness, quite to the unknown as barbarism. In this way, we will see that the perspective of evolution throws us into the paradigm of barbarism, in the sense that not everything new is necessarily innovative, as not everything old is outdated.
\end{abstract}

Keywords: barbarism; transhumanism; evolution; otherness; beyond.

How to cite: Colang, G., \& Vlad, L. (2020). Transhumanism as Barbarism. Logos Universality Mentality Education Novelty: Philosophy \& Humanistic Sciences, 8(1), 33-43. doi: 10.18662/lumenphs/8.1/34 


\section{Introduction}

Over time, man has evolved from a natural state to a civilized one. The events that have marked mankind led to an adaptation to new cultural trends, etc. Postmodernity has also attracted a change in values, unlike those supported by modernity within its legitimate structures. At the same time, the evolution of technology and technique has led to the emergence of mutations in terms of man and his way of being in the world: values have changed, the man replacing physical work with robotic work, etc. New technologies have also made their presence felt in the medical field, currently being able to perform operations and treat diseases that until recently were incurable. Also, man has tried to find a substitute for divinity in technology, since the fact is currently aimed at building technologies through which man can extend his life indefinitely. With the help of these technologies, the human will be able to download his mind into a digital device, but what we cannot know exactly is whether the feelings and other specifically human psychic processes could be digitized. This is just an example we have brought to the fore, in the context in which the idea of this article is to analyze transhumanism as a form of barbarism.

\section{Barbarism as an exaggerated otherness}

In Ancient Greece, the barbarian was not fluent in Greek, he was practically devoid of the gift of articulation, so he was symbolically the foreigner par excellence. At the same time, at Romans, the barbarian was the individual beyond the fortress, without too many rights and who in one form or another, was the feared enemy. Basically, from these two perspectives we have now in the collective mentality the idea that the barbarian is in a continuous state of opposition to the civilized (Lilley, 2013). However, as the barbarian attracts with him the opposition, especially on a pejorative note, the civilized distances itself into a positive key. Although we are talking about symbolism, today we have the idea that barbarism is in itself lightless. But, for this work, barbarism must be seen as a way of differentiation, exaggerated otherness, refined barbarism, or why not, human fundamental nature.

To the same extent, as we will see, barbarism comes from within, and this shows us that it does not perish, but transforms itself over and over again (Colang, 2018). Thus, the new perspectives of understanding of the human being, whether they are psychologists or anthropologists, cannot be broken by the idea of barbarism as an exaggerated otherness. In this sense, 
any epistemic mode of fundamental human understanding, ontological, technical, ontic, will have its roots in barbarism. Moreover, any kind of epistemic overcoming at the human level, will not necessarily lead to a new form of barbarism, as some thinkers assert, but even to barbarism itself. Not to say, but the barbarism does not change unitarily but retains its tentacles from within the civilization itself. After all, civilization is nothing more than a refined form of barbarism.

The idea that the barbarian is essentially evil, that it can be seen only through the eyes of otherness, has been preserved from the collective mind: "Externality can have a geographical character: the foreigner, the barbarian, the Other - outside the borders are then hired; but it can also take on the form of the inner vampire; in this case the crazy man, the alcoholic is slaughtered; the Jew, the sexual degenerate, the other - from within the self and the social body, this time" (Roudinesco, 1995). However, in today's world the barbarian is no longer necessarily the individual at the end of the city, but the man who - par excellence - stands out through its eccentricity. In this context, we have to deal with mass superiors, that is, individuals from everyday life who are trying to step out of the ordinary, out of the average every day, as Heidegger said. On the other hand, we have an economically useful barbarians of cheap labor.

From another perspective, we also have leisure classes - in Veblen's language (Verblen, 2009) or white collars in Sutherland`s (Sutherland, 1940), refined barbarians who claim to possess a kind of sophistication just because they have the capital and allow themselves to buy the social-symbolic image and even spread it under the empire of the pecuniary: "intensive commercialization equal loss of soul [...] here finds its foundation one of the great common places that always hide under the guise of barbarians: the thought that they represent greed as opposed to culture; the certainty that they move driven by a hypertrophic, almost immoral, thirst for profit, sales, earnings" (Baricco, 2009).

And then, from the mix of a win-win society, civilization turns rather symbolically into a refined barbarism from which refined barbarians control the poor without voice and power. Things, in essence, do not differ from those of antiquity, when barbarians were deprived of any kind of humanity, sent to the end of the citadel and pointed at for each misfortune: "It is a myth that barbarism is unique to the twentieth century: the whole of human history includes wars, massacres, and all kinds of torture and cruelty: there are grounds for thinking that over much of the world the changes of the last hundred years or so have been towards a more humane climate than at any previous time" (Glover, 2000). 
Keeping the logic above, we can say then that the current world has not evolved spiritually, but technologically, in the sense that the great questions of philosophy are still current, that people's fears are the same. If the average man is barbaric but claims to be civilized just because he is surrounded by a wealth of sophisticated gadgets, then the whole of humanity has a problem. As we know, the technical evolution did not stop the massacre, nor did it increase in interest the crimes against humanity. At the same time, we should see where we end up if we start with a simple way to reduce human nature to technique: "Diderot once noted that the transition from fanaticism to barbarism is but one step and if present trends continue there is every reason for grim forebodings. What we know about past ages of barbarism is frightening enough; the consequences of aggressive madness in the age of high technology and the era of weapons of mass destruction may well be beyond our imagination" (Laquer, 1999).

In this sense, the transformation of the ordinary man, by resorting to sophistication techniques and ideologies of transposition into virtual lives, or excessive somatization, merely plunges the man into barbarism, because we must not forget, barbarism was par excellence, the different, the misunderstood, the exaggerated otherness from the end of the world. In this logic, transhumanism is a process, like many others, of transforming man into a mass superman, into the new barbarian, hollowed out to perfection, emptied of existence, passed through the filter of propagating machines of various advertising messages. Paradoxal, although seeking authenticity, sinks into mediocrity.

At the same time, transhumanism, as an expression of barbarism, can only remain symbolically situated in the idea of otherness. Also, the progress, seen as human perfection, from a Cartesianism view, in postmodernism is transforming. Unlike modernism, postmodernity allows itself to be relativized, so to go wrong. In this sense, Transhumanism, or the Superhuman as ultra-biologism, neuro-transformism, or other posthuman approaches, are in themselves fallacies into barbarism, in the sense that barbarism was and is exaggerated alterity on the axis of time (Fabian, 1983). In this way, for the great mass, any overcoming of the human condition leads to barbarism. Further, we will see what transhumanism entails, how it was born, and what its direction would be. At the same time, we will see to what extent progress can be considered as spiritual perfection or if it still makes sense to consider the problem in these terms. 


\section{Transhumanism as an expression of barbarism}

The current barbarian man can be thought from a philosophical perspective as a superhuman. If it is to take into account the Nietzschean perspective, then the superhuman is the product of a society in which the moral values of the society are replaced by the values that the individual creates for himself. Barbarism would rather mean the overthrow of all values through postmodernism or trans-modernism. In our opinion, technique and technology have influenced the way in which man manifests himself in the world, these being considered another face of barbarism. About technical barbarism, thinkers like Mark Helprin (2009) Jean-François Mattéi (2005), and Alexandru Dragomir (2010) have discussed extensively, as we will see in the following pages. In this sense, any thought towards a new barbarism through trans-humanism becomes as current as possible.

Transhumanism is an international philosophical and cultural current that has brought together researchers from various fields to support human bio-enhancement (Vlad, 2019). Man is trying to substitute divinity with the help of technologies, in this sense technologies are being developed for the prolongation of life, proposing to substitute the eternal life promised in the holy books by copying and transferring the consciousness into the cloud (Douglas \& Săvulescu, 2010).

The human will pass from one ontological condition to another, thus becoming posthuman (Sandu, 2015), the posthuman condition is that condition in which all limitations have been overcome (Sandu \& Vlad, 2018), including the communicative one (Frunză, 2018). Analyzing the transhumanist ideas, we underline the fact that this current borrow a series of myths of Modernity that it recontextualizes: the myth of progress, the myth of reason or the myth of the superhuman (in addition to the myth of the earthly paradise, etc.) (Vlad, 2019). What is desired by bio-improvement technologies is to bring the human of the present homo sapiens species to a new stage of evolution. This stage (posthuman condition) (Sandu \& TerecVlad, 2016) implies the overcoming of the biological limitations (Schussler, 2019) that the present human species has, while also seeking to reach the demi-God condition.

In the following, we will analyze the transhuman man as a future barbarian, starting from the ideas of human bio-enhancement and the implicit consequences of the technology as an extension of the human body, as well as the philosophical implications that arise from the fact that barbarism can be transhumanism. 


\section{Bio-enhancement of the moral dimension of progress}

Over time, man has tried to overcome his condition and become like a god; the arguments to support this claim are the transfer of consciousness (which comes from Buddhist traditions), Frankenstein, alchemy, the Golem, etc. Nowadays, thanks to the discoveries in the field of technology and the emergence of niche disciplines, the man has reached the point where he can use genetic engineering to create children according to their wishes (in this category we can introduce the two deaf lesbians as well, who wish to bring a child with the same disability to the world) (Huidu, 2019; Săvulescu, 2002). If it is to take a look back, then it is easy to observe that even during the Nazi period, human experiments were carried out in order to provide the Aryan species with a longer life span.

In the last century, the relationship between technique and man was analyzed by Martin Heidegger (1982), and the human condition by Hannah Arendt (2007). Nowadays, the relationship between technology and the individual is analyzed by Verbeek (2006), who supports the theory of mediation, according to which technologies begin to merge with the human body. Together with him, Don Ihde analyzes the relation of man with technology from the perspective of post-phenomenology (Ihde, 1995). These philosophical analyzes and perspectives are complemented by those coming on the (bioethics), neuroscience, etc. What is wanted to be emphasized is that through the new technologies and the ones of reproduction it has been possible to create a mouse from two epithelial cells from two male mice (Cutas \& Smajdor, 2016), an aspect that in our opinion leads to a series of mutations of the family.

Through these examples we have highlighted the fact that man uses technology to bio-enhance, but what cannot be foreseen for now is that we cannot know if the current value system will be the same as for the generations to come. As an argument for this is the fact that the ethics of modernity is different from the ethics of the society which we belong, and for this reason, we cannot know whether ethics of future generations, not present (Terec-Vlad, 2016) will be similar to the ethics of the society of which we belong. The possibility of having a slave morality again, and one of the master's morality as in Nietzschean philosophy, is quite large given that the power relations are different. In this context, the transhumanist philosophers believe that this is not the problem, but we cannot know if the information will reach the hands of those who shouldn't have it, as has happened many times in history (Hiroshima). 
Moral bio-enhancement is analyzed by Persson and Săvulescu (2014) who argue that artificial improvement is necessary so that humanity avoids possible catastrophes, when only so we could act better so as not to affect the lives of future species, animals, plants and even possible human species. For many years, the question of the ethics of technology designers and the role they play in the daily life of man has been raised. What needs to be emphasized is the need for an assessment of how the end-user uses bioenhancement technology and what the end-goal of this use is (Fenton, 2010). The new perspectives of understanding the human have their roots also in barbarism (but this time a new form), this being understood as a refined barbarism. Transhumanism and everything that attracts this movement remain symbolically situated in the idea of otherness.

\section{Transhumanism and axiology}

Transhumanism has given birth to new forms of religiosity (pseudo religions, in our opinion). The posthuman condition of the individual, the emergence of AI, and other human or nonhuman life forms have led researchers in the field of transhumanism to develop new ideas regarding religiosity. What is interesting to say is that a number of ideas are taken from Christianity, such as artificial immortality, paradise, a global brain like God. The trans-religiousness sought by the followers of transhumanism is neither religious nor areligious, but it tries to capture what lies beyond any religion, thus avoiding any kind of conflict that might have a religious basis. For the technologized man, the forms of religiosity present so far in the history of religions have no interest anymore, because through the new technologies he has already obtained the immortality promised in the holy books.

Barbarism being defined here as a cultural transposition, a symbolic change from within itself, assumes transhumanism as a process of progress. In this sense, barbarism, as some thinkers show it, has brought with it the change from within itself: „hell, behold, are never the others, as a widespread sophistry state, hell is always ourselves, from the moment the interiority closes to any external opening. This does not mean that the barbarian would be in us, [...] but it means that barbarism rises, as a boat breaks its ropes at the first strong gust of wind when the ego revolts against this light or this interiority that he will call «idea» or «face». Barbarism is both desertion of the self and regression of the self' (Mattéi, 2005). After all, if we look at history, the barbarian was at the outskirts of the fortress, he was always used economically: on the one hand as a cheap labor force, and on the other as an otherness, as different, as a chain, as Cioran says, placed by 
the chosen people when converting culturally, colonizing, etc. (Cioran, 2008) So barbarism is closely connected with nihilism, with deconstruction, and this sets in motion - as Nietzsche tells us, the very essence of humanity (Nietzsche, 2001). Practically, transhumanism, with its multiple forms, enters this paradigm of barbarism, in the sense that any symbolic change from the norm arrives hermeneutically in the space of the vanishing point, just as in projective geometry, that is, it returns to its origins. Practically, by expanding the meaning of barbarism, everything related to a possible change of human nature is ultimately a barbarism, in the sense of removal from the source, a Nietzschean transvaluation that becomes foreign to humanity. In this way, we are dealing with an exaggerated otherness that becomes completely different from what we are used to perceiving as normality, that is, exactly what barbarism was in ancient times and even more.

That is why we now speak of a digital barbarism, in the sense that natural language is replaced by a specific, technical language, because the barbarism originally, if we return to the Greeks, was precisely the impossibility to speak correctly, to speak Greek. Therefore, today we have a different approach, but in the same paradigm, as Mark Helprin shows us: "We no longer fall in love, we have a relationship, and not with a girl or a boy or a man or a woman, but with a "significant other." A question pertaining to one sex or another is now an "issue" "relevant" to one "gender" or another. And we do not drink water but, rather, in imitation of laboratory instructions or machine manuals, "hydrate" ourselves. Language, for its beauty, has as its compass the heart. In imitation of machine-speakas far from the root and magnificence of language as it is possible to get without just grunting - this has been left behind to die" (Helprin, 2009). In this way, we are dealing with the mechanization of language, that is, with a departure from tradition and norm. And then transhumanism can only be possible by modifying natural language and adapting it to a more symbolic process, in fact, a language conducive to the development of programming language, but poor from a human perspective, after all. This is also pointed out by Alexandru Dragomir: "The specific of our individuality is destroyed in any industrial product. My foot is no longer this foot, it's number 39. And so, with the others. I can choose the model, the size, and the quality of a product, but I choose between abstracts, and that's important. The transition from concrete to abstract is the transition to the spiritual world. Our world is not so much (and necessarily) a uniform world but above all an abstract world." (Dragomir, 2010). 


\section{Conclusions}

In this paper we have shown that any form of overcoming the human condition can be a form of barbarism. Thus, any idea that implies progress does not necessarily involve spiritual evolution. Of course, for the current thinking, spirituality is no longer interesting, all being excessive somatization. In practice, morality becomes an extension of the will of power, where moral values are transformed into market values. The human being is in this sense financial, it is no longer an end in itself, as Kant said, but an approximation of medicine in the way of so-called evolution. The current man, transfigured, adapted to market demands, becomes barbaric every time he sets out to change his condition. Barbarism being an exaggerated otherness, so revulsion, causes man to flee from himself just to reach himself. The metaphysical stakes, in the end, is still fear but transformed into an existential earthquake. The somatic improvement, the derivation of moral norms from purely technical axioms, the reversal of values, all the deeds of refinement under the pretext of development represents the anxiety of the barbarian man transformed into the will of power in the face of life or existence. By opposing situation, as Heidegger said, the current barbarian becomes the new barbarian. Thus, barbarism was about otherness, about the fact that it was incomprehensible, foreign, now through any form of transformation, over-technicalization, barbarism comes back, is current, comes to light. In essence, nothing has changed; after all, progress does not necessarily mean evolution.

\section{References}

Arendt, H. (2007). Condiţia umană. Design \& Print.

Baricco, A.. (2009). Barbarii. Eseu despre mutatie. Humanitas.

Cioran, E. (2008). Căderea în timp. Humanitas.

Colang, G. (2018). Dimensiuni şi perspective etice asupra barbariei actuale. Eikon.

Douglas, T., \& Savulescu, J. (2010). Synthetic biology and the ethics of knowledge. Journal of Medical Ethics, 36(11), 687-693.

Dragomir, A. (2010). Meditații despre epoca modernă. Humanitas.

Fabian, J. (1983). Time and the Other: How anthropology makes its object. Columbia University Press.

Fenton, E. (2010). The perils of failing to enhance: A response to Persson and Savulescu. Journal of Medical Ethics, 36(3). 148-151. 
Frunză, S. (2018). Our daily body and its instrumental role in communication. Aurel Codoban's reading „body as language”. Journal for the Study of Religions and Ideologies, 17(50). 140-156.

Glover, J. (2000). Humanity: A moral history of the Twentieth Century. Yale Nota Bene. Heidegger, M. (1982). Întrebare privitoare la tehnică în Originea operei de artă. Univers.

Helprin, M. (2009). Digital barbarism. A writer's manifesto. Harper Collins Publishers E-Books.

Huidu, A. (2019). Parsson and Săvulescu's "Unfit for the future" or the starting point for the deconstruction of the concept of parentality. Postmodern Openings, 10(1), 200-219. https://doi.org/10.18662/po/63

Ihde, D. (1995). Postphenomenology. Essays in the postmodern context. Northwestern University Press.

Laquer, W. (1999). Fanaticism and the arms of mass destruction. Oxford University Press. Lilley, S., (2013). Transhumanism and society: The social debate over human enhancement. Springer.

Mattéi, J. F. (2005). Inner barbarism. Essay on the modern world. Parallela 45.

Nietzsche, F. (2001). Daybreak: Thoughts on the prejudices of morality. Cambridge University Press.

Persson, I., \& Săvulescu, J. (2014). Neadaptați pentru viitor. Nevoia de bioameliorare umană. All.

Roudinesco, E. (1995). De la Sigmund Freud la Jacques Lacan. Humanitas.

Sandu, A. (2015). The anthropology of immortality and the crisis of posthuman conscience. Journal for the Study of Religions and Ideologies, 14(40), 3-26.

Sandu, A., \& Terec-Vlad, L. (2016). A phenomenological perspective on transhumanism from the perspective of the spoken of being. Postmodern Openings, 7(1), 67-76. https://doi.org/10.18662/po/2016.0701.05

Sandu, A., \& Vlad, L. (2018). Beyond technological singularity - The posthuman condition. Postmodern Openings, 9(1), 91-102. https://doi.org/10.18662/po/07

Săvulescu, J. (2002). Deaf lesbians, „designer disability”, and the future of medicine. Journal of Medical Ethics, 325, 771-773.

Schussler, A. E. (2019). Transhumanism as a new techno-religion and personal development: In the framework of a future technological spirituality. Journal for the Study of Religions and Ideologies, 18(53), 92-106.

Sutherland, E. H. (1940). White-collar criminality. American Sociological Review, 5(1), $1-12$ 
Terec-Vlad, L. (2016). The principle of responsibility towards the human nonpresence or the non-human presence. Postmodern Openings, 7(2), 79-89. https://doi.org/10.18662/po/2016.0702.06

Verbeek, P. (2006). Materializing morality: Design ethics and technological mediation. Sciencce, Technology and Human Values, 31(3), 361-380.

Vlad, L. (2019). Umanism, transumanism, postumanism. Perspective filosofice. Lumen. 